\title{
VESTIBULAR NEURONITIS
}

\author{
Shahdevi Nandar Kurniawan ${ }^{1}$, Afiyfah Kiysa Waafi ${ }^{2}$ \\ ${ }^{I}$ Department of Neurology, Faculty of Medicine, Brawijaya University \\ ${ }^{2}$ Medical Profession Study Program, Faculty of Medicine, Universitas Brawijaya, Malang, Indonesia.
}

Correspondence : shahdevinandar@ub.ac.id

\begin{abstract}
Vestibular neuronitis is an acute vestibular syndrome due to inflammation of the vestibular nerve characterized by the typical symptoms of acute rotatory vertigo accompanied by nausea, vomiting, and symptoms of balance disorders. The incidence of vestibular neuronitis is about 3.5 per 100,000 people. The exact etiology of this vestibular neuronitis is unknown. However, based on existing evidence, vestibular neuronitis is associated with viral infections of the upper respiratory tract and herpes zoster infection. The clinical manifestations of vestibular neuronitis are persistent rotatory vertigo accompanied by oscillopsia, horizontal-rotatory peripheral vestibular spontaneous nystagmus on the healthy side, and a tendency to fall on the affected side. Diagnosis of vestibular neuronitis can be made by clinical diagnosis, through history, physical examination, and special examinations. Through these examinations, the differential diagnosis of vestibular neuronitis should be excluded, such as Meniere's disease, labyrinthitis, benign paroxysmal positional vertigo, and vertigo due to central lesions such as cerebellar infarction. Management of vestibular neuronitis is in the form of symptomatic therapy with vestibular suppressants, antivertigo, and redirect to relieve the symptoms that arise, then causative therapy can be done by administering corticosteroids, and in patients, physiotherapy can be done to improve vestibular function.
\end{abstract}

Keyword : Vestibular neuronitis, vertigo, nystagmus, vestibular nerve

\section{PENDAhULUAN}

Vestibular neuronitis dengan gejala utama berupa vertigo akut yang parah dapat bertahan selama berjam-jam hingga berhari-hari. Gejala tersebut seringkali disertai dengan mual muntah yang dapat menyebabkan kondisi kehilangan cairan yang masif, serta disertai kondisi gangguan keseimbangan, sehingga pasien kesulitan untuk berjalan dan memiliki kecenderungan untuk jatuh (1). Hal-hal tersebut dapat menimbulkan kondisi yang tidak nyaman pada pasien, dan mengurangi kualitas hidup pasien.

Inflamasi yang terjadi pada nervus vestibularis dapat terjadi setelah adanya infeksi saluran napas atas atau infeksi herpes zoster, oleh karena itu, dapat terjadi peningkatan kejadian vestibular neuronitis paska kejadian outbreak penyakit infeksi saluran napas atas. Memperbaiki fungsi vestibular perifer pasien merupakan tujuan utama dari terapi vestibular neuronitis, sehingga diharapkan dengan terapi yang diberikan didapatkan perbaikan yang signifikan dari fungsi vestibular, sehingga pasien dapat memiliki kualitas hidup yang cukup baik (2).

\section{Definisi}

Vestibular neuronitis merupakan sindroma vestibular akut yang disebabkan oleh inflamasi nervus vestibularis yang dikarakterisasi dengan vertigo akut dan disertai dengan mual, muntah, serta gejala gangguan keseimbangan (3). Terminologi yang digunakan, yaitu neuronitis atau disebut juga neuritis merujuk pada hubungan sindroma vestibular dengan penyakit pernapasan akibat virus atau sinusitis dan peningkatan respon antibodi dalam serum terhadap HSV1. Vestibular neuronitis ditandai dengan adanya degenerasi sel ganglion dan akson fokal pada nervus vestibularis dengan adanya episode vertigo yang rekuren (durasi $\geq 1$ jam tanpa adanya gangguan pendengaran) (4).

\section{Epidemiologi}

Insiden vestibular neuronitis mencapai sekitar 3,5 per 100.000 orang. Ini adalah penyebab paling umum ketiga dari gangguan vestibular perifer, dengan benign paroxysmal positioning vertigo (BPPV) menempati urutan pertama dan penyakit Meniere di urutan kedua. Vestibular neuronitis menyumbang sekitar 7\% dari pasien gangguan vestibular perifer. Onset usia pasien vestibular neuronitis biasanya diantara usia 30-60 tahun dan distribusi usia stabil pada usia 40-50 tahun. Tidak didapatkan data perbedaan seksual yang signifikan secara epidemiologis (5).

\section{Etiologi}

Etiologi pasti dari vestibular neuronitis ini masih belum diketahui, namun penelitian-penelitian sebelumnya menunjukkan bahwa infeksi akibat virus merupakan salah satu etiologi vestibular neuronitis. Terdapat beberapa bukti pendukung terhadap teori infeksi virus sebagai etiologi vestibular neuronitis.

\section{Article History}

Received: August 18, 2021; Accepted: : August 30, 2021; Published: : September 1, 2021

Cite As: Vancouver style

Kurniawan SN, Waafi AK. Vestibular neuronitis. Journal of Pain, Vertigo and Headache; 2021.2:44-48 
Seringkali vestibular neuronitis didahului oleh gejala seperti $\mathrm{flu}^{2}$. Histopatologi dari saraf vestibular pada kasus vestibular neuronitis memiliki gambaran yang menyerupai gambaran pada kasus herpes zoster oticus. Pada pemeriksaan polymerase chain reaction (PCR) pada sampel hasil di daerah ganglia vestibular manusia dengan vestibular neuronitis mendeteksi adanya DNA HSV-1 pada 2/3 sampel, selain itu, ditemukan pula latency associated transcript dan infiltrasi sel T CD8+ pada $70 \%$ ganglia vestibular hasil di daerah pada kasus vestibular neuronitis. Hal-hal yang telah disebutkan mengindikasikan bahwa ganglia vestibular terinfeksi HSV-1 secara laten (5).

\section{Patofisiologi}

HSV-1 yang diperkirakan sebagai kandidat terkuat etiologi vestibular neuronitis diasumsikan berada dalam keadaan laten di ganglia vestibular, misalnya di inti nukleus seperti yang telah dilaporkan di saraf kranial lainnya. Kemudian karena faktor penyerta, virus tiba-tiba bereplikasi dan menginduksi inflamasi dan edema, sehingga menyebabkan kerusakan sel sekunder pada sel ganglion vestibular. Vestibular neuronitis lebih sering mengenai bagian superior dari nervus vestibularis, yang menyuplai bagian kanalis anterior dan horizontal, termasuk utrikulus dan sebagian sakulus. Hal ini mungkin disebabkan karena kanal tulang yang lebih panjang dan lebih sempit, serta adanya suplai ganda pada bagian inferior telinga (6).

Rotatory vertigo dan nystagmus berputar spontan ke sisi yang sehat yang merupakan manifestasi utama dari vestibular neuronitis disebabkan oleh ketidakseimbangan tonus vestibular antara labirin yang intak dan labirin yang terganggu. Perbedaan tonus vestibular tersebut terjadi karena nervus vestibular tetap aktif walaupun tanpa pergerakan kepala, frekuensi potensial aksi saat fase istirahat mencapai sekitar $100 \mathrm{~Hz}$. Kecenderungan untuk jatuh ke sisi lesi diakibatkan karena kompensasi reflek vestibulospinal yang berlebihan akibat ketidakseimbangan tonus (6).

\section{Manifestasi Klinis}

Manifestasi klinis dari vestibular neuronitis diantaranya adalah sebagai berikut:

- Vertigo rotatory persisten dengan osilopsia sisi yang sehat

- Horizontal-rotatory peripheral vestibular spontaneous nystagmus daerah sisi yang sehat

- Kemiringan patologis dari visual subjektif vertikal daerah labirin yang sakit

- Deviasi gait dan kecenderungan untuk jatuh daerah sisi yang sakit

- Mual dan muntah

- Defisit fungsional kanal horizontal unilateral

Fase awal vestibular neuronitis dimanifestasikan dengan kehilangan fungsi yang nyata umumnya ditandai dengan vertigo yang parah, pusing (dizziness), dan kecenderungan untuk jatuh. Keluhan tersebut disertai dengan rasa sakit, mual, dan muntah. Keluhan tersebut akan hilang perlahan selama 1-2 minggu. Pasien biasanya bebas gejala dalam waktu 3-5 minggu saat istirahat (6). Pemulihan tersebut dapat terjadi akibat:
1. Kompensasi sentral dari ketidakseimbangan tonus vestibular perifer

2. Restorasi fungsi vestibular perifer (generally incomplete)

3. Substitusi hilangnya fungsi dengan sistem vestibular yang sehat, termasuk somatosensory (propriosepsi leher) dan input visual ${ }^{6}$.
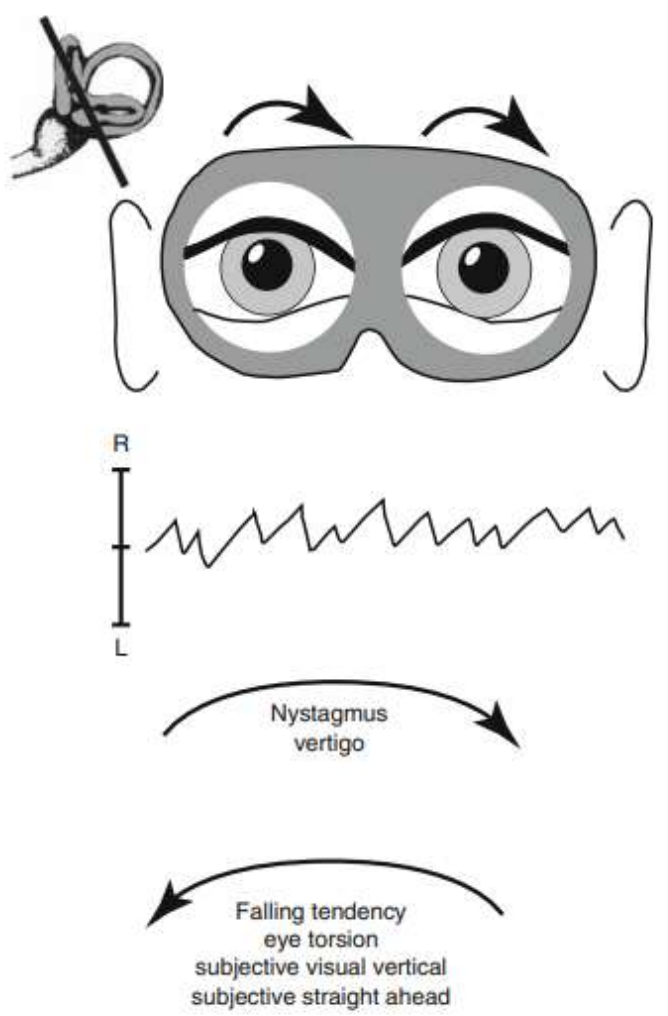

Gambar 1. Nistagmus Spontan dan Vertigo ke Sisi Lesi dan Kecenderungan Jatuh ke Sisi Sehat pada Vestibular Neuronitis (6)

\section{DIAGNOSIS}

Pada anamnesis pasien dapat mengeluhkan gejala utama dari vestibular neuronitis, yaitu defisit vestibular unilateral akut, berupa vertigo rotatorik dengan ilusi pergerakan dari lingkungan sekitar atau disebut dengan oscillopsia, selain itu, keluhan juga disertai dengan ketidakseimbangan gaya berjalan serta postural dengan kecenderungan untuk jatuh dan disertai mual dan muntah. Gejala-gejala tersebut memiliki onset yang akut atau subakut dan bertahan hingga beberapa hari sampai beberapa minggu. Gejala tersebut dapat bertambah parah ketika pasien menggerakkan kepala, sehingga pasien cenderung mencari tempat dan suasana yang sepi. Pasien juga perlu ditanyakan apakah terdapat gangguan pendengaran, tinnitus, atau defisit neurologis yang lain, karena gejala-gejala tersebut tidak masuk ke dalam kriteria diagnosis dari vestibular neuronitis (6).

Pendekatan pada pasien dengan keluhan vertigo adalah membedakan vertigo sentral atau perifer. Pada vertigo akut juga perlu disingkirkan kemungkinan penyebab sentral, seperti iskemia atau perdarahan cerebellar atau batang otak. Kepada pasien perlu ditanyakan dan dilakukan pemeriksaan fisik untuk mengetahui adanya tanda dan gejala defisit neurologis lain, seperti kelemahan atau perubahan sensasi 
Tabel 1. Diagnosis banding vertigo perifer (7)

\begin{tabular}{lllll}
\hline Diagnosis Banding & Onset dan Durasi & Faktor pencetus & Manifestasi khusus & Hasil Pemeriksaan Fisik \\
\hline Labirinitis & Beberapa detik - menit & $\begin{array}{l}\text { Perubahan posisi } \\
\text { kepala }\end{array}$ & Tinnitus & $\begin{array}{l}\text { Didapatkan gangguan } \\
\text { pendengaran }\end{array}$ \\
\hline $\begin{array}{l}\text { Vestibular } \\
\text { Neuronitis }\end{array}$ & Jam - hari & $\begin{array}{l}\text { Infeksi saluran } \\
\text { pernapasan atas }\end{array}$ & $\begin{array}{l}\text { Ketidakseimbangan, } \\
\text { nystagmus horizontal } \\
\text { atau rotational dengan } \\
\text { komponen cepat } \\
\text { menjauhi sisi lesi }\end{array}$ & $\begin{array}{l}\text { Tidak ada gangguan } \\
\text { pendengaran }\end{array}$ \\
\hline $\begin{array}{l}\text { Bening Paroxysmal } \\
\text { Positional Vertigo }\end{array}$ & Detik & $\begin{array}{l}\text { Perubahan posisi } \\
\text { kepala }\end{array}$ & Posisional & Dix-Hallpike positif \\
\hline Meniere's disease & Jam & Spontan & $\begin{array}{l}\text { Gangguan pendengaran } \\
\text { dan tinnitus }\end{array}$ & $\begin{array}{l}\text { Gangguan pendengarana } \\
\text { sensorineural }\end{array}$ \\
\hline
\end{tabular}

Tabel 2. Pemeriksaan HINTS (8).

\begin{tabular}{ccll}
\hline & Pemeriksaan & \multicolumn{1}{c}{ Vestibular Neuronitis } & \multicolumn{1}{c}{ Stroke Cerebellar } \\
\hline HI & Head impulse test & $\begin{array}{l}\text { Koreksi mata yang sakadik kearah target } \\
\text { visual ketika kepala dirotasikan ke sisi lesi, } \\
\text { tidak ada koreksi mata sakadik ketika kepala } \\
\text { dirotasikan ke sisi kontralateral lesi }\end{array}$ & $\begin{array}{l}\text { Koreksi mata yang sakadik ke arah target visual } \\
\text { ketika kepala dirotasikan ke sisi lesi atau } \\
\text { kontralesi (bergantung pada lokasi stroke), } \\
\text { namun lebih umum didapatkan pemeriksaan } \\
\text { head impulse test yang negatif }\end{array}$ \\
\hline $\mathbf{N}$ & Nystagmus type & $\begin{array}{l}\text { Spontaneous jerk nystagmus, menjauhi sisi } \\
\text { lesi dengan arah tetap }\end{array}$ & Direction-changing atau gaze-evoked nystagmus \\
\hline TS & Test of Skew & TIdak ada skew deviation & Terdapat skew deviation \\
\hline
\end{tabular}

Tabel 3. Obat-obatan yang dapat digunakan pada vertigo akut yang disertai dengan mual dan muntah (6)

\begin{tabular}{ll}
\hline Nama Obat & Dosis \\
\hline Meclizine (Antivert) & $12.5-50 \mathrm{mg}$ PO setial 4-8 jam \\
\hline Dimenhydrinate & $25-100 \mathrm{mg}$ PO, IM, atau IV setiap 4-8 jam \\
\hline Diazepam & $2-10 \mathrm{mg}$ PO atau IV setiap 4-8 jam \\
\hline Lorazepam & $0.5-2 \mathrm{mg}$ PO, IM, atau IV setiap 4-8 jam \\
\hline Metoclopramide & $5-10 \mathrm{mg}$ PO atau IV lambat setiap 6-8 jam \\
\hline & $5-10 \mathrm{mg}$ PO atau IM setiap 6-8 jam \\
Prochlorperazine & $25 \mathrm{mg}$ perrektal setiap 12 jam \\
& $5-10 \mathrm{mg}$ IV lambat selama 2 menit \\
\hline Promethazine & $12.5-25 \mathrm{mg}$ PO, IM, atau perrektal setiap 4-12 jam \\
\hline
\end{tabular}

(nyeri, suhu, atau rasa kebas) pada ekstremitas atau wajah, gangguan bicara, perubahan penglihatan termasuk diplopia, disfagia, perubahan suara, gangguan memori, atau ataksia, selain itu juga perlu dilakukan pemeriksaan mengenai gait dan keseimbangan, dengan melakukan pemeriksaan Romberg's sign dan heel-toe test serta mencari tanda-tanda lesi cerebellar, seperti disdiadokokinesia, dismetria, dan tremor. Gejala-gejala tersebut dapat mengindikasikan adanya penyebab sentral ${ }^{7}$.

Pemeriksaan fisik lain yang dapat dilakukan adalah pemeriksaan telingan dengan otoskop, untuk melihat adanya infeksi atau inflamasi pada telinga luar serta juga diperlukan pemeriksaan pendengaran, untuk melihat apakah terdapat gangguan pendengaran atau tidak. Apabila didapatkan gangguan pendengaran, juga diperlukan penentuan gangguan pendengaran konduksi atau sensorineural. Pada kasus vestibular neuronitis umumnya tidak didapatkan gangguan pendengaran. Pemeriksaan mata perlu dilakukan untuk mengevaluasi nistagmus. Dari pemeriksaan nistagmus juga dapat membantu menentukan vertigo yang terjadi oleh karena lesi sentral atau perifer. Nistagmus oleh karena lesi sentral dapat horizontal, rotasional, atau vertikal dan tidak menghilang oleh fiksasi visual, sedangkan nistagmus tipe perifer dapat hilang dengan fiksasi visual (7).

\section{Pemeriksaan Khusus}

Prioritas diagnostik pada pasien dengan gejala vertigo akut dengan kecurigaan vestibular neuronitis, yaitu harus dibedakan antara vestibular neuronitis dengan penyebab sentral dari vertigo akut, seperti infark serebellar. Hal tersebut dapat dilakukan dengan melakukan pemeriksaan klinis yang disebut dengan pemeriksaan HINTS (tabel 2) (8).

Pada head impulse test pasien diminta untuk melihat ke hidung pemeriksa dan kemudian pemeriksa secara repat memutar kepala pasien 10-20 derajat. Didapatkan hasil abnormal atau positif apabila mata pasien secara cepat dan berulang (pergerakan mata sakadik) gagal untuk refiksasi ke hidung pemeriksa. Hasil yang positif mengindikasikan adanya gangguan reflek vestibuler-okular ${ }^{7}$. Tes Romberg juga dapat dilakukan pada pasien, yaitu dengan meminta pasien untuk mempertahankan keseimbangan dengan posisi kedua kaki rapat yang pertama dengan mata terbuka, kemudian dengan mata tertutup. Pada vestibular neuronitis pasien akan mendapatkan hasil Romberg's sign yang positif, yaitu gagal mempertahankan keseimbangan pada kondisi mata tertutup. Apabila pasien gagal mempertahankan keseimbangan pada kedua mata terbuka dapat mengindikasikan lesi serebellar (2). 


\section{Pemeriksaan Penunjang}

Pemeriksaan laboratorium seperti darah lengkap dan elektrolit tidak rutin dilakukan untuk pasien dengan keluhan utama vertigo. Pemeriksaan laboratorium dapat dilakukan apabila pada pasien terdapat tanda dan gejala yang mengarah ke kondisi kausatif lain. Pemeriksaan radiologis termasuk $C T$ Scan, MRI, atau MRA dapat diindikasikan, apabila:

- Hasil pemeriksaan tidak konsisten dengan lesi perifer

- Terdapat faktor resiko CVA yang prominen

- Tanda dan gejala defisit neurologis

- Gejala vertigo disertai dengan nyeri kepala(9)

Caloric testing merupakan pemeriksaan untuk memeriksa setiap labirin secara terpisah dengan cara memproduksi nistagmus dengan stimulasi suhu. Pasien ditempatkan di posisi dimana kanalis semisirkularis horizontal menjadi berposisi vertikal (elevasi kepala 30 derajat). Irigasi dengan suhu dingin menyebabkan terjadinya nistagmus dengan komponen cepat ke arah telinga yang berlawanan dari telinga yang diirigasi. Apabila dilakukan irigasi dengan air hangat, maka komponen cepat nistagmus akan mengarah ke telinga yang diirigasi. Terdapat mnemonic yang mudah untuk diingat, yaitu COWS "cold opposite, warm same”. Caloric testing binaural bithermal menggunakan stimuli dengan suhu $30^{\circ}$ dan $44^{\circ} \mathrm{C}$, dan setiap kanal diirigasi selama 30 detik dengan $250 \mathrm{~mL}$ air. Terdapat periode istirahat 5 menit diantara irigasi. Metode umum untuk menghitung respon caloric adalah dengan mengkomputasi kecepatan tertinggi dari komponen lambat nistagmus yang merefrleksikan intensitas dari respons vestibular. Untuk membandingkan respon telinga kanan dan telinga kiri dapat menggunakan formula Jongkees' untuk menentukan presentasi penurunan respon vestibular. Penurunan respon vertibular $>24 \%$ menunjukkan adanya lesi vestibular perifer (10).

\section{Diagnosis Banding}

Terdapat beberapa diagnosis banding dari vestibular neuronitis. Yang pertama ditinjau dari gejala utamanya, yaitu vertigo perifer, terdapat beberapa diagnosis banding, seperti pada tabel 1 (7). Selain itu, terdapat beberapa diagnosis banding yang lain, yaitu apabila dari hasil pemeriksaan didapatkan keraguan jenis vertigo oleh karena sebab sentral atau horizontal, maka tetap perlu mempertimbangkan kemungkinan penyebab vertigo sentral sebelum dipastikan vertigo yang terjadi adalah karena penyebab perifer. Diantara diagnosis banding tersebut adalah perdarahan atau iskemia cerebellar, perdarahan atau iskemia batang otak, diseksi arteri vertebralis, dekompresi telinga dalam, gangguan kapsul otik akibat patah tulang temporal, multiple sklerosis, disrupsi kapsul otik akibat trauma (1).

\section{TATA LAKSANA}

Prinsip tatalaksana vestibular neuronitis adalah terapi simtomatik, terapi penyebab, dan perbaikan kompensasi vestibular sentral. Pada terapi simtomatik yang pertama perlu dilakukan stabilisasi kondisi pasien. Apabila didapatkan riwayat kehilangan cairan yang massif akibat muntah, maka diperlukan stabilisasi dengan pemberian resusitasi cairan. Pilihan untuk terapi simtomatik dapat diberikan obat antivertigo dan antiemetik untuk membantu meringankan keluhan mual dan muntah. Antivertigo dapat diberikan 100 mg dimenhydrinate. Apabila pasien tidak toleransi dengan pemberian peroral dapat diberikan secara parenteral. Selain itu juga dapat diberikan terapi suportif antiemetic seperti metochlopramid atau ondansetron. Vertigo akut yang menyebabkan mual dan muntah juga dapat disupresi dengan vestibular suppressants, seperti obat-obat golongan benzodiazepine, termasuk diazepam, clonazepam, dan lorazepam. Selain dapat mengsupresi vestibular dengan menginhibisi secara sentral melakui reseptor gamaaminobutyric acid, golongan benzodiazepine juga dapat berfungsi sebagai anxiolytic yang membantu menenangkan pasien. Pemberian obat golongan benzodiazepine harus segera dihentikan apabila gejala vertigo dan nistagmus mereda. Hal tersebut untuk menghindari efek samping, seperti sedasi, habituasi, gangguan memori, dan kompensasi vestibular yang jelek $(4,6)$.

Untuk terapi penyebab dapat diberikan kortikosteroid, yaitu methylprednisolone dengan dosis awal $100 \mathrm{mg} / \mathrm{hari}$. Dosis methylpredinosolone dapat diturunkan bertahap sebesar 20 mg setiap 4 hari. Terapi dengan kortikosteroid terbukti memperbaiki secara signifikan fungsi vestibular perifer. Meskipun terdapat bukti-bukti bahwa vestibular neuronitis disebabkan oleh infeksi HSV1 yang menyebabkan inflamasi dari nervus vestibularis, namun masih terdapat bukti yang cukup mengenai efikasi antivirus untuk manajemen terapi vestibular neuronitis (6).

Untuk memperbaiki kompensasi vestibular sentral, dapat dilakukan pemrograman latihan fisik bertahap dibawah pengawasan fisioterapis. Tahap pertama dapat dilakukan stabilisasi statis, kemudian dilakukan latihan dinamis untuk pergerakan kepala, kontrol keseimbangan, dan stabilisasi pandangan ketika pergerakan mata-kepala-badan. Efikasi dari fisioterapi dalam memperbaiki kompensasi vestibulospinal sentral pada pasien dengan vestibular neuronitis telah dibuktikan pada studi klinis (6).

\section{PROGNOSIS}

Pada perjalanan penyakit vestibular neuronitis, fungsi vestibular perifer tidak kembali spontan pada sebagian besar pasien. Pada penelitian dengan 60 pasien vestibular neuronitis, didapatkan $90 \%$ pasien setelah 1 bulan dan $80 \%$ pasien setelah 6 bulan tetap memiliki defisit dari fungsi vestibular perifer. Pada penelitian lain didapatkan hanya sekitar $42 \%$ kasus vestibular neuronitis yang dapat beresolusi spontan. Angka rekurensi jangka panjang dari vestibular neuronitis mencapai $2-11 \%^{6}$.

\section{KESIMPULAN}

Vestibular neuronitis merupakan penyebab paling umum ketiga dari gangguan vestibular perifer. Etiologi dari vestibular neuronitis hingga saat ini masih belum sepenuhnya dipahami, namun, bukti-bukti menunjukkan bahwa etiologi dari vestibular neuronitis berhubungan dengan terjadinya infeksi saluran napas atas dan herpes zoster. Penegakan diagnosis vestibular neuronitis dapat dilakukan dengan penegakan diagnosis klinis, yaitu dengan anamnesis, pemeriksaan fisik, dan pemeriksaan tambahan. Pemeriksaan penunjang caloric testing dapat dilakukan untuk 
membedakan vertigo akibat lesi sentral atau lesi perifer. Tatalaksana dapat dilakukan dengan pemberian terapi simtomatis, terapi penyebab dengan kortikosteroid, dan rehabilitasi untuk memperbaiki fungsi vestibular. Pengobatan antivirus hingga sejauh ini masih belum terbukti efikasinya.

\section{ACKNOWLEDGMENT}

Penulis menyampaikan ucapan terima kasih kepada Fakultas Kedokteran Universitas Brawijaya dan Rumah Sakit Umum Daerah dr. Saiful Anwar Malang yang telah memfasilitasi penulis dalam pembuatan artikel review ini.

\section{DAFTAR PUSTAKA}

1. Goddard JC, Fayad JN. Vestibular neuritis. Otolaryngologic Clinics of North America; 2011. Apr 1;44(2):361-5. DOI: 10.1016/j.otc.2011.01.007

2. Zaidi SH, Sinha A. Vertigo: A clinical guide. Springer Science \& Business Media; 2013. Jun 24.

3. Rudmik L. Evidence-based clinical practice in otolaryngology. Elsevier Health Sciences; 2018. ISBN: 978-3-642-36485-3

4. Chen L and Halmagyi GM. Vestibular neuritis and labyrinthitis; 2014.
5. Bronstein A, editor. Oxford textbook of vertigo and imbalance. OUP Oxford; 2013 Feb 21.

ISBN: 9780199608997

6. Brandt T, Dieterich M, Strupp M. Vertigo and dizziness common complaints second edition. Springer-Verlag London Limited; 2013. ISBN: 978-0-85729-591-0

7. Dommaraju S, Perera E. An approach to vertigo in general practice. Australian Journal of General Practice; 2016. Apr 1;45(4):190. Avalalaible from: racgp.org.au/afp/2016/april/an-approach-to-vertigo-ingeneral-practice/

8. Hwang E, Tse D. Evidence-Based Practice: Management of acute vertigo. Evidence-Based Clinical Practice in Otolaryngology; 2018 Jan 20.

DOI: 10.1016/B978-0-323-54460-3.00001-4

9. Kanegaonkar R, Tysome J, editors. Dizziness and vertigo: An introduction and practical guide. CRC Press; 2014. Apr 22. ISBN: 9781444182682

10. Swaiman KF, Ashwal S, Ferriero DM, Schor NF, Finkel RS, Gropman AL, Pearl PL, Shevell M. Swaiman's pediatric neurology e-book: Principles and practice. Elsevier Health Sciences; 2017 Sep 21.

ISBN: 9780323374811 